ECONOMICA

\title{
BEHAVIOR OF BINGKUANG TRADERS IN APPLYING ISLAMIC BUSINESS ETHICS WITH MODERATING PERSONALITY
}

\author{
By \\ Susriyanti' ${ }^{1}$, Sitti Rizki Mulyani' ${ }^{2}$, Fitri Yeni' ${ }^{3)}$ \\ 1) Management Department, UPI "YPTK" Padang, Indonesia \\ Email: susriyanti@upiyptk.ac.id \\ 2) Management Department, UPI "YPTK" Padang, Indonesia \\ Email: sittirizki@gmail.com \\ 3) Management Department, UPI "YPTK” Padang, Indonesia \\ Email: fitri_yeni@upiyptk.ac.id \\ Submitted: 2020.12.17 Reviewed: 2021.04.08 Accepted:2021.04.30 \\ https://doi.org/10.22202/economica.2021.v9.i2.4585
}

\begin{abstract}
The purpose of this research is to see how the behavior of frame traders in the city of Padang in applying Islamic business ethics with personality as moderating. The research gap in this research is when the phenomenon was discovered that in the last 3 years the land for bingkuang plantations in the city of Padang has decreased by almost one third, the authors also found the phenomenon of different behavior patterns of the frame traders when trading based on the observations made. The state of the art of this research is by adding indicators to each variable and using sentence statement questionnaires that the authors modify in the team. Respondents in this study were the traders in the city of Padang with 101 samples. The research methodology used is to measure the validity and reliability of the data, simple linear regression, moderating regression analysis (MRA), $t$ test and determination test $(R 2)$. From the results of partial testing with a simple regression of Islamic business ethics (X1) and personality (X2-moderating), a positive and significant effect on trader behavior. Whereas the MRA test of Islamic business ethics has a positive and significant effect on the behavior of traders, but personality does not have a strong influence in moderating between the two. From the results of the determination test shows that without moderation, Islamic business ethics is able to explain the overall behavior of traders by $62.8 \%$ and with the moderation of the ability to explain the independent variables to the dependent variable as a whole increased to $64.1 \%$.
\end{abstract}

Jel Classification:

D23;L48; K

Keywords: behavior of frame traders, personality, Islamic business ethics 


\section{INTRODUCTION}

Currently, there are a lot of bingkuang traders that have sprung up in the city of Padang, especially in areas that are the exit areas from the city of Padang since there are no longer intercity bus terminals. Among them are in the Tanjung Saba Pitameh area, Bandar Buat, Lubuk Buaya border, Teluk Bayur, and in Fresh Water. These areas which are used as trading areas for frames are the terminal areas that have emerged. With uniform types of merchandise and limited consumers, of course there is very sharp competition between one trader and another in competing for buyers. From the results of the direct survey we conducted on September 5 and 7 2019, there were 101 bingkuang traders scattered in these areas below, with details that can be seen in table 1 below:

Table 1. Number of Traders at Several Locations in Padang City

\begin{tabular}{lr}
\hline Location & Total \\
\hline Tanjung Saba Pitameh & 14 \\
Lubuk Buaya & 40 \\
Batas Kota Lubuk Buaya & 32 \\
Gaung Teluk Bayur & 6 \\
Air Tawar & 7 \\
Bandar Buat & 2 \\
\hline Source: Author's Survey Results (7 September, 2019)
\end{tabular}

The number of buyers or consumers who tend to like these fronds is very limited because of the various types of other fruits available. These other fruits can be an alternative choice for buyers. However, as a fruit that characterizes the city of

The number of buyers or consumers who tend to like these fronds is very limited because of the various types of other fruits available. These other fruits can be an alternative choice for buyers. However, as a fruit that characterizes the city of Padang, bingkuang always gets a certain place as an option for buyers. Consumers who make a lot of purchases are those from outside the city of Padang. So that the number of local tourist visits, holidays, weekends, are factors that greatly affect the sales turnover of these junk traders.

The data on the number of tourist visits to West Sumatra from 2012 - 2016 can be seen in table 2 below:

Table 2. Number of Local Tourist

\begin{tabular}{cr}
\hline Year & Number of Tourists \\
\hline 2012 & 5.850 .033 \\
2013 & 6.261 .364 \\
2014 & 6.605 .738 \\
2015 & 6.973 .678 \\
2016 & 7.343 .282 \\
\hline Source: West Sumatra Tourism Statistics \& Profile Data 2017
\end{tabular}

From table 2 above, we can see that the number of tourist visits to West Sumatra has increased from time to time. The number of visits is, of course, spread to all areas in West Sumatra, including the city of Padang. We assume this data can represent a picture of a visit to the city of Padang as the capital of West Sumatra. By increasing the number of tourist visits to West Sumatra in general and to the city of Padang in particular, of course this will be an opportunity for bingkuang traders to increase their sales. 
Currently, the application of the sharia system in various fields of business activities, including trade, banking, hospitality, tourism, and other fields, has also triggered the birth of a business application with Sharia ethics. (Amalia, 2012). Islamic business ethics aims to teach people to cooperate, to help, and to distance themselves from envy and grudges and things that are not in accordance with sharia. Islamic business ethics also functions as a control (controller) of the economic activity of trade, because philosophically ethics bases itself on scientific and religious reasoning to judge. The basis of this assessment in the practice of life in society, we often find that religiously there are values that will bring humans to human happiness, welfare and safety both in life in this world and in the life in the hereafter. (Hakim, 2012).

The difference between this study and previous research is the dimensions and indicators used. In research conducted by Nurjanah Nasution (2019), the indicators used to see business behavior are 6 indicators, namely: 1) selling halal goods, 2) being right, trustworthy and honest, 3) upholding justice and forbidding flowers, 4) implementing affection and forbidding monopoly, 5) upholding tolerance and brotherhood, 6) having the principle of trading is a provision for the afterlife. Whereas in this study the authors also used the six indicators by adding 2 more indicators, namely tagwa and aqshid, so that the number of indicators I used became 8 indicators. To see Islamic Business Ethics, Nurjanah uses 5 indicators, namely: 1) unity, 2) balance, 3) free will to think, 4) responsibility, 5) ihsan, meanwhile the author adds 3 other indicators, namely selling by oath, shiddiq and tabligh. In looking at personality, Nurjanah uses 5 indicators, namely: 1) extravertion, 2) agreeableness, 3) conscientiousness, 4) neorotissm, 5) openness experience, while the author adds 2 more indicators, namely being happy and having the principle of living based on religion.
In addition to Islamic norms that must be fulfilled in order to achieve maslahah (the goal of Islamic sharia), important economic ethical values are included as a supporting factor in achieving a maslahah. (Hidayat, 2018). The ethical dimension of the economy and the practical dimension (business) have an economic goal, namely material benefits, so that profit becomes the edeology of doing business, even though it must sacrifice ethical moral values. The purpose of making a profit is often used as an excuse for every business actor or trader to conduct business practices that are not moral and even haram (N. J. Nasution, 2019).

Some of the phenomena that the author finds on bingkuang traders in the city of Padang are the tendency of the uneven prices set by traders in the same area to buyers. Meanwhile, buyers tend not to have realized it beforehand. They only realized this when they shared information with other fellow buyers, such as relatives, friends, at other times. Buyers who come to traders generally do not search or match prices with other traders in the same area. Buyers always assume that all prices offered are the same. So after there is an agreement, buyers usually buy right away and walk away if they don't agree. Buyers who disagree have a tendency not to buy in that area except in other areas.

Another phenomenon that the writer got from observations was the dishonesty of some traders in saying that the condition of the frame was new or not. There are traders who say the scraps are new even though they are left over from yesterday. There are also traders who honestly say that this frame is the remnants of yesterday's merchandise. From the observations made, the writer also gets different selling attitudes and selling languages. There are sellers who are friendly, have good language, and always smile at the buyers. There are also sellers who tend to be rude, have bad language, and have faces that don't smile at all. This is presumably because each seller has a different 
personality from one another. It is also suspected that the traders' backgrounds also influence their ethical attitudes and behavior in trading. Personality is one of the factors that will influence a person's success when running his business. In the business world, certain characters and personalities are needed to be strong so that they can compete in certain situations.

The research gap in this study we get from the existence of a statement which reveals that the production of frames continues to decline from tracing https://www.harianhaluan.com/news/detail 168903/petani-bengkuang-terus-berkurangdi-kota-padang, Tuesday, February 11, 2020. "Currently there are about 10 hectares of land used by farmers to produce bengkuang in Padang City," said the Head of the Padang City Agriculture Office, Syaiful Bahri to the bow, Wednesday (21/2/2018). He conveyed, Kuranji and Koto Tangah are two areas that still produce yam. The lack of desire of farmers in Padang City to produce yam is due to a lack of demand from consumers.

The data taken from the bow in 2015, Pemko Padang once stated that that year there were still 23 hectares of yam production land. This means that in the last 3 years, more than half of the yam production land in Padang City has decreased. "Lack of demand is the cause of the decrease in yam farmers in Padang City. Because this is the same as business, if there is a lot of demand, of course it will also be proportional to the amount of production, "he said.

Today, behavior is an important value in trading (Choi \& Hwang, 2019; Quintelier, 2014). In the Big Indonesian Dictionary, behavior is an individual response or reaction that manifests itself in gestures (attitudes), not just body or speech.

Behavior in everyday life is often equated with behavior, mannerisms, and ways of behaving. Behavior is human behavior whose process is not planned in his genes or which does not arise instinctively, but as something that must be made his own by learning (Ifigeneia \& Prokopis, 2020; Osveh \& Abbas, 2018). A person's behavior is often formed because of habituation that can be deliberate or not (Ndun et al., 2019). Behavior has a fairly broad meaning, so that it includes all statements or expressions, meaning not just actions but also words, written expressions and gestures (Emmerik \& Euwema, 2007; Indarti et al., 2017).

A trader is a person who trades, trades goods that are not self-produced for profit (Church et al., 2015). There are traders who trade on a large scale such as distributors, there are also traders who trade on a small scale such as shops, and there are also retailers and street vendors. Most of the bingkuang traders in the city of Padang are street vendors.

Economic behavior is subjective not only in consumer behavior, but also in traders' behavior. As with consumer behavior, the behavior of traders is not only influenced by their rational knowledge but also by the system of values they believe. Entrepreneurs or traders also base their economic behavior with a set of ethical beliefs. Behavior that strengthens one's personality, namely friendliness (Tauni et al., 2017). Entrepreneurial economic behavior does not merely consider right and wrong factors according to economics and law or based on experience, but also considers good and bad factors according to ethics. (Wazin, 2014).

A trader is a person who trades, trades goods that are not self-produced for profit (Church et al., 2015). There are traders who trade on a large scale such as distributors, there are also traders who trade on a small scale such as shops, and there are also retailers and street vendors. Most of the bingkuang traders in the city of Padang are street vendors.

Economic behavior is subjective not only in consumer behavior, but also in traders' behavior. As with consumer behavior, the behavior of traders is not only influenced by their rational knowledge but also by the system of values they believe. 
Entrepreneurs or traders also base their economic behavior with a set of ethical beliefs. Behavior that strengthens one's personality, namely friendliness (Tauni et al., 2017). Entrepreneurial economic behavior does not merely consider right and wrong factors according to economics and law or based on experience, but also considers good and bad factors according to ethics. (Wazin, 2014).

Islamic business behavior is behavior that is built based on the principles of the Qur'an and the Hadiths that will lead the perpetrators to achieve success in the hereafter. (Faradiska \& Asytuti, 2019; Haryanti \& Wijaya, 2019). The ethical standards of sharia business conduct educate business people in running their business with (Hassan, 2016): (1) Taqwa. The Qur'an commands to seek and achieve the priorities that Allah SWT has set for humans, among others: (a) Should prioritize the search for a great and lasting reward in the hereafter rather than small and limited profits in the world, (b) Give priority to something that is morally clean rather than something that is morally dirty even though the benefits are great, (c) Putting the work that is lawful rather than what is haram. (2) Aqshid. Namely simple, humble, gentle, polite (sympathetic). (3) Khidmad. It means serving well. Attitude to serve is the main attitude of business people and an important part of this attitude of service is courtesy and humility. (4) Trust. Islam wants business people to have a living heart so that they can protect the rights of Allah SWT, the rights of others, and their own rights, can protect behavior that destroys the mandate given to them, be able to maintain and be accountable to Allah SWT.

Ethics according to terminology is a systematic study of the character of the concept of values, good, bad, right, wrong and so on. Ethics are general principles that justify us to apply anything. Here ethics is interpreted as the basis of a person's morality and at the same time the philosopher in his behavior. Ethical issues are problems related to human existence, in all aspects of life, both individuals and society, both in relation to God, fellow humans and themselves, as well as with the surrounding nature, both in relation to human existence in the social, economic, political fields., culture and religion (Abuznaid, 2009; Hassan, 2016)

Islamic business ethics are Islamic ethical values in business activities that have been presented in the perspective of Al-Qur'an and Hadith, which are based on 6 principles, namely truth, belief, sincerity, brotherhood, knowledge, and justice (Dwiatma, 2019). Islamic business ethics positions business as a human effort to seek the pleasure of Allah SWT. Therefore, in principle, knowledge of business ethics in Islam absolutely must be possessed by every businessman / trader, especially in facing business competition which has now entered the era of globalization to avoid various kinds of actions prohibited by Allah SWT. (Abuznaid, 2009; Hassan, 2016; Ismaeel \& Blaim, 2012).

As for business ethics in Islam which refers to the leadership traits of the Prophet Muhammad SAW in trading, they are as follows (Juliana et al., 2019; Musa et al., 2020): (a) Siddiq is always telling the truth, being honest or having high personal integrity. (b) Istiqamah is to have a characteristic that is consistent with the truth that comes from Allah SWT. (c) Fattanah is trustworthy, responsible and always able to complete duties and obligations. (d) Tabliqh is the ability to be able to convey, communicate correctly, convey the truth, and be able to educate and direct people, to know the rules and laws of Allah SWT and His Messenger.

Personality is one of the key determinants of human behavior (Ashill et al., 2020; Church et al., 2015; Tauni et al., 2017). Personality is the total ways in which an individual acts on and interacts with others (Robbin \& Judge, 2015). Personality is the number of inherited or hereditary tendencies with various influences from the environment and 
education, which shape a person's mental condition and influence his attitude towards life. (Seibokaite \& Endriulaitiene, 2012). From these definitions it can be concluded that personality is a typical and predictable style of behavior and traits in a person, which is used to react and adapt to stimuli, so that the behavior pattern is a unique functional unit for individuals.

The uniqueness of this research lies in the dimensions and indicators used to measure each of the variables. In this study, the authors added dimensions and indicators. This difference will be further explained in Chapter II, precisely in Table 3 in this study. The goal of this study is to see how the application of Islamic business ethics to the behavior of bingkuang traders in the city of Padang and to see how personality is able to moderate the application of Islamic business ethics to the behavior of bingkuang traders in the city of Padang.

\section{METHODS}

The research method is a scientific method used to obtain data for specific purposes and uses (Sugiyono, 2017). This research can be classified into field research (field research) using a quantitative approach, namely a process of finding knowledge that uses data in the form of numbers as a tool to determine the provisions regarding what you want to know. (Sujarweni, 2015). This research was also conducted to see how much influence, how the slope direction (direction slots) of the influence that was formed, from Islamic Business Ethics on the Behavior of Border Traders in the city of Padang with personality as a moderating variable. This research can also be said as a quantitative descriptive study.

The location of this research was conducted in the city of Padang as the object of research. The subjects of this study were the bingkuang traders in the city of Padang who were used as resource persons or respondents. This research will be conducted within a period of 1 year, from September 2019 to August 2020.

The population in this study were bingkuang traders in the city of Padang, at predetermined locations, amounting to 101 traders. Population is the overall data from the object of a study. The sample in the study will be taken using the census method. In the census method, all populations will be sampled. So the sample in this study were 101 respondents, according to the existing population.

Based on the introduction and theoretical foundations, the authors set the hypothesis as follows:

H1. It is assumed that the application of Islamic business ethics has a positive and significant effect on the behavior of bingkuang traders in the city of Padang.

$\mathrm{H} 2$. It is assumed that personality is able to strongly moderate the application of Islamic business ethics to the behavior of bingkuang traders in the city of Padang.

\section{RESULTS AND DISCUSSION Validity and Reliability Test}

The results of the validity and reliability tests in total from all statements used can be seen in table 3 below:

Table 3. Simple Regression Test Results

\begin{tabular}{lcc}
\hline \multicolumn{1}{c}{ Variabel } & $\begin{array}{c}\text { KMO and } \\
\text { Bartlett Test }\end{array}$ & Cronbach Alpha \\
\hline Behavior & 0.804 & 0.814 \\
Islamic Business Ethics & 0.839 & 0.928 \\
Personality & 0.768 & 0.750 \\
Source: Data Processed With SPSS 25, 2020
\end{tabular}

Based on the test results in table 3 above, it can be seen that all statements used are declared valid because they have a KMO value greater than 0.5. All statements used 
were declared reliable because they had a Cronbach alpha value greater than 0.6.

This shows that all statement items which are indicators of this variable are valid and worthy of use in this study because they have been able to represent what we want to know or what we want to see in this study. So that future researchers can also use these statements if they want to research the same problem.

Table 4. Simple Regression Test Results

\begin{tabular}{cccc}
\hline Variable & Constant & Unstandardieze B & Sig \\
\hline $\begin{array}{c}\text { Islamic Business Ethics> } \\
\text { Behavior }\end{array}$ & 28.576 & 0.533 & .000 \\
$\begin{array}{l}\text { Personality> Behavior } \\
\text { Source: Data Processed With SPSS }\end{array}$ & 55.499 & 0.252 & .007 \\
\hline
\end{tabular}

Based on table 4 above, the results of a simple regression test between Islamic Business Ethics and Merchant Behavior are obtained as follows:

$\mathrm{Y}=\mathbf{2 8 , 5 7 6}+\mathbf{0 , 5 3 3 X} 1+\mathrm{e}$

From this equation it can be interpreted that the constant value indicates that if Islamic Business Ethics is absent / neglected / has zero value, then Trader Behavior will still be formed at the existing constant value of 28, 576. Meanwhile, Islamic Business Ethics as variable $\mathrm{X} 1$ has a positive influence on Trader Behavior of 0.533 . This means that if Islamic Business Ethics get better or improve, then the Trader's Behavior will also be better for the number of interceptions that exist. Likewise if the opposite happens.

The application of good Islamic business ethics can also increase the good behavior patterns of traders in carrying out their activities. Likewise, on the other hand, if the application of Islamic business ethics is not carried out properly, the behavior patterns of traders can also become unfavorable. So that traders who know, realize, understand and truly understand Islamic business ethics will better and better understand how to behave in their trading activities.
Based on table 4 above, the results of a simple regression test between personality and trader behavior are obtained as follows: $\mathrm{Y}=\mathbf{5 5 , 4 4 9}+\mathbf{0 , 2 5 2 X 1}+\mathrm{e}$

From this equation it can be interpreted that the constant value indicates that if the Personality is absent / neglected / zero then the Trader's Behavior will still be formed at the existing constant value of 55, 449. Meanwhile, Personality as a variable $\mathrm{X} 2$ has a positive influence on Trader Behavior of 0.252. This means that if the Personality gets better or improves, then the Trader's Behavior will also be better for the number of interceptions that exist. Likewise if the opposite happens.

Personality can also contribute to the behavior patterns of traders in carrying out their trading activities. So that a good personality will create good behavior patterns, and a bad personality will also create bad behavior patterns.

\section{MRA Test Result}

The results of the equation test with the MRA will be presented in table 5 below:

Table 5. MRA Test Results

\begin{tabular}{cccc}
\hline Variable & Constant & Unstandardieze B & Sig \\
\hline Islamic Business Ethics & \multirow{2}{*}{30.015} & .438 & .000 \\
Personality & & .002 & .101 \\
\hline Source: Data Processed With SPSS 25, 2020 & &
\end{tabular}

Based on the results obtained from table 5 above, the MRA regression test results can be obtained with the following equation: 
$\mathrm{Y}=30,015+0,438 X 1+0,002(\mathrm{X} 1 \mathrm{X} 2)+\mathrm{e}$

Based on the equation from the MRA test results above, it is found that a constant value of 30.015 indicates a value that will remain in Trader Behavior even though Islamic Business Ethics and Personality do not exist or are ignored or are zero. From the MRA test, Islamic Business Ethics has a positive influence on Trader Behavior of 0.438. And the ability of Personality to influence or moderate the Trader's Behavior is a positive amount of 0.002 .

If Islamic business ethics are properly implemented by traders and encouraged or equipped with a good personality, the traders' behavior patterns will become even better. This means that this personality is able to increase or decrease the ability of traders to apply Islamic business ethics to behave.

\section{T-test}

We can see the results of the $t$ test with simple regression using table 5, it is known that the significance value without moderation is 0.000 less than 0.05 . This means that Islamic Business Ethics has a significant effect on the Behavior of Bingkuang Traders in the city of Padang. Meanwhile, with moderation based on the $t$ test with MRA, it is known that the significance value of Islamic Business Ethics on Trader Behavior remains significant at 0.000 . However, personality as moderation does not have a significant effect on trader behavior because it has a sig value of 0.101> 0.05 as the level of significancy.

The application of Islamic business ethics has a strong and considerable influence in shaping the behavior patterns of bingkuang traders in Padang City in a straight line with a personality as moderation or not. However, the personality ability as a moderator between the two is not strong enough.

\section{$\mathbf{R}^{2}$ Test}

What percentage of the contribution of Islamic Business Ethics to Trader Behavior without moderation and moderation can be seen in table 6 below:

Table 6. R2 Test Results

\begin{tabular}{cccc}
\hline Model & R & R Sq & Adj R Sq \\
\hline No Moderation & $0.628^{\mathrm{a}}$ & 0.394 & 0.388 \\
With Moderation & $0.641^{\mathrm{a}}$ & 0.410 & 0.398 \\
\hline Source: Data Processed With SPSS 25,2020 & &
\end{tabular}

Based on table 6, it can be seen that the ability of Islamic Business Ethics to explain Trader Behavior as a whole is $62.8 \%$. This means that there are $37.2 \%$ other things that influence the behavior of bingkuang traders in the city of Padang outside the variables under study.

Whereas when there is moderation, the ability of Islamic Business Ethics to explain Trader Behavior is known to have the R2 value of $64.1 \%$. This means that there are $35.9 \%$ of other variables that have an influence in explaining Trader Behavior outside of Islamic Business Ethics as a whole.

\section{CONCLUSION}

Based on the results of research testing, it was found that the application of Islamic business ethics to the behavior of bingkuang traders in the city of Padang plays a positive and significant role. This means that if the application of Islamic Business Ethics is getting better and higher, the behavior of traders will also be better and higher in serving consumers when shopping. Conversely, if the application of Islamic Business Ethics is not good or bad, it will also have a bad impact on the behavior of bauxite traders in this city in trading. If moderated by the application of Islamic Business Ethics Personality on the behavior of bingkuang traders in the city of Padang, it still plays a positive but insignificant role. 
This means that the personality ability to moderate Islamic Business Ethics with the behavior of bingkuang traders in the city of Padang is not strong or weak. This is indicated by the insignificance of the personality sigd value of the trader behavior.

\section{REFERENCES}

Abuznaid, S. A. (2009). Business ethics in Islam: the glaring gap in practice. International Journal of Islamic and Middle Eastern Finance and Management, 2(4), 278-288. https://doi.org/10.1108/17538390911 $\underline{006340}$

Amalia, F. (2012). Implementasi Etika Bisnis Islam Pada Pedagang Di Bazar Madinah Depok. Prosiding Seminas, l(2).

http://journal.unipdu.ac.id/index.php/ seminas/article/view/134

Ashill, N. J., Semaan, R. W., Gibbs, T., \& Gazley, A. (2020). Personality trait determinants of frontline employee customer orientation and job performance: a Russian study. International Journal of Bank Marketing, 38(5), 1215-1234. https://doi.org/10.1108/IJBM-11$\underline{2019-0407}$

Choi, L., \& Hwang, J. (2019). The role of prosocial and proactive personality in customer citizenship behaviors. Journal of Consumer Marketing, 36(2), 288-305. https://doi.org/10.1108/JCM-012018-2518

Church, H. A., Rotolo, T. C., Alyson, M., \& Matthew, J. D. G. (2015). The Role of Personality in Organization Development: A Multi-Level Framework for Applying Personality to Individual, Team, and Organizational Change. In Research in Organizational Change and Development (Vol. 23, pp. 91-166).
Emerald Group Publishing Limited. https://doi.org/10.1108/S0897301620150000023003

Dwiatma, B. K. (2019). Etika Bisnis Islam Dalam Pelayan Haji dan Umroh. Jurnal Ilmu Dakwah Dan Pembangungan, 39(2), 183-196.

Emmerik, H. V. I. H., \& Euwema, M. C. (2007). Who is offering a helping hand?: Associations between personality and OCBs, and the moderating role of team leader effectiveness. Journal of Managerial Psychology, 22(6), 530-548. https://doi.org/10.1108/02683940710 $\underline{778422}$

Faradiska, D., \& Asytuti, R. (2019). Pengaruh Penerapan Etika Bisnis Islam, Religiusitas, Dan Kreativitas Terhadap Keuntungan Pengusaha Konfeksi. SERAMBI: Jurnal Ekonomi Manajemen Dan Bisnis Islam, 1(3), 81-90.

https://doi.org/10.36407/serambi.v1i3 .125

Hakim, L. (2012). Internalisasi Nila-nilai Agama Islam Dalam Pembentukan Sikap dan Perilaku Siswa Sekolah Dasar Islam Terpadu Al-Muttaqin Kota Tasikmalaya. Jurnal Pendidikan Agama Islam Ta'lim, 10(1), 67-77. http://jurnal.upi.edu/file/5_Penanama n_Nilai.pdf

Haryanti, N., \& Wijaya, T. (2019). ANALISIS PENERAPAN PRINSIP-PRINSIP ETIKA BISNIS. 4(2), 122-129.

Hassan, A. (2016). Islamic ethical responsibilities for business and sustainable development. Humanomics, 32(1), 80-94. https://doi.org/10.1108/H-07-2015$\underline{0047}$

Hidayat, F. (2018). Pengaruh etika bisnis Islam dan religiusitas terhadap perilaku bisnis syariah pada pengurus HIPSI Kota Semarang (Doctoral dissertation, UIN Walisongo 
Semarang).

In http://eprints.walisongo.ac.id/8859/.

Ifigeneia, L., \& Prokopis, T. (2020). How do personality traits affect visitor's experience, emotional stimulation and behaviour? The case of wine tourism. In Tourism Review: Vol. ahead-of-p (Issue ahead-of-print). https://doi.org/10.1108/TR-05-2019$\underline{0148}$

Indarti, S., Solimun, Fernandes, A. A. R., \& Hakim, W. (2017). The effect of OCB in relationship between personality, organizational commitment and job satisfaction on performance. Journal of Management Development, 36(10), 1283-1293.

https://doi.org/10.1108/JMD-11$\underline{2016-0250}$

Ismaeel, M., \& Blaim, K. (2012). Toward applied Islamic business ethics: Responsible halal business. Journal of Management Development, 31(10), 1090-1100.

https://doi.org/10.1108/02621711211 281889

Juliana, J., Faathir, M., \& Sulthan, M. A. (2019). Implementasi Etika Bisnis Islam Pelaku Usaha Mikro: Studi Kasus Pada Pelaku Usaha Mikro Syariah Puspa Bank Indonesia Wilayah Jawa Barat Di Bandung Tahun 2017. Strategic: Jurnal Pendidikan Manajemen Bisnis, 19(1), 36.

https://doi.org/10.17509/strategic.v19 i1.17663

Musa, M. A., Sukor, M. E. A., Ismail, M. N., \& Elias, M. R. F. (2020). Islamic business ethics and practices of Islamic banks: Perceptions of Islamic bank employees in Gulf cooperation countries and Malaysia. Journal of Islamic Accounting and Business Research, 11(5), 1009-1031. https://doi.org/10.1108/JIABR-072016-0080
Nasution, F. N., \& Rafiki, A. (2019). Islamic work ethics, organizational commitment and job satisfaction of Islamic banks in Indonesia. RAUSP Management Journal, 55(2), 195205. https://doi.org/10.1108/RAUSP01-2019-0011

Ndun, A. V. E., Arjana, I. G. B., \& Robertus. (2019). Pengaruh Persepsi, Sikap, dan Perilaku terhadap Soft Skill Peserta Didik SMA Kristen 2 Kupang. Ciencias: Jurnal Penelitian Dan Pengembangan Pendidikan, 2(1), 114.

Osveh, E., \& Abbas, A. (2018). Linking personality traits and individuals' knowledge management behavior. Aslib Journal of Information Management, 70(3), 234-251. https://doi.org/10.1108/AJIM-012018-0019

Quintelier, E. (2014). The influence of the big 5 personality traits on young people's political consumer behavior. Young Consumers, 15(4), 342-352. https://doi.org/10.1108/YC-09-201300395

Robbin, S. P., \& Judge, T. A. (2015). Organizational Behaviour. In Jakarta: Salemba Empat.

Seibokaite, L., \& Endriulaitiene, A. (2012). The role of personality traits, work motivation and organizational safety climate in risky occupational performance of professional drivers. Baltic Journal of Management, 7(1), 103-118.

https://doi.org/10.1108/17465261211 $\underline{195892}$

Sugiyono. (2017). Metode Penelitian Kuantitatif, Kualitatif, dan R\&D. In Bandung: Alfabeta, $C V$.

Sujarweni, V. W. (2015). Metode Penelitian Bisnis dan Ekonomi. In Yogyakarta. Pustaka.

Tauni, M. Z., Rao, Z. U. R., Fang, H., Mirza, S. S., Memon, Z. A., \& Jebran, K. 
(2017). Do investor's Big Five personality traits influence the association between information acquisition and stock trading behavior? China Finance Review International, 7(4), 450-477. https://doi.org/10.1108/CFRI-062016-005

Wazin. (2014). Relevansi Antara Etika BIsnis Islam dengan Perilaku Wirausaha Muslim (Studi tentang Perilaku Pedagang di Pasar Lama Kota Serang Provinsi Banten). In Jurnal Penelitian Sosial Keagamaan Vol. 1 No.1. 